Journal of Bangladesh Academy of Sciences, Vol. 38, No. 2, 131-142, 2014

\title{
HYDROGEOLOGICAL INVESTIGATIONS OF CHAPAI NAWABGANJ TOWN OF NAWABGANJ DISTRICT, NORTH-WEST BANGLADESH USING ISOTOPE AND OTHER TECHNIQUES
}

\author{
ZAKIR HOSSAIN*, KHAIRUL BASHAR, RATAN KUMAR MAJUMDER, \\ MAZEDA ISLAM AND MIZANUR RAHMAN SARKER \\ Department of Geological Sciences, Jahangirnagar University, Savar, Dhaka-1342, \\ Bangladesh
}

\begin{abstract}
Groundwater of Chapai Nawabganj town has been studied using hydrogeological, hydrochemical and environmental isotope $\left(\delta^{18} \mathrm{O}, \delta^{2} \mathrm{H}, \delta^{13} \mathrm{C},{ }^{3} \mathrm{H}\right.$ and $\left.{ }^{14} \mathrm{C}\right)$ data. Aquifer underneath the study area is divided into unconfined to semi-confined Holocene alluvial floodplain aquifer and confined Plio-Pleistocene Dupi Tila sandstone aquifer. Chemical composition of groundwater is characterized by high concentrations of $\mathrm{Mg}^{2+}, \mathrm{Na}^{+}, \mathrm{Ca}^{2+}, \mathrm{HCO}_{3}{ }^{-}, \mathrm{Fe}^{\text {Total }}$, and low concentrations of $\mathrm{Mn}^{2+}, \mathrm{NO}_{3}{ }^{-}$and $\mathrm{PO}_{4}{ }^{3-}$. Groundwater samples are mainly $\mathrm{Mg}-\mathrm{Ca}-\mathrm{HCO}_{3}$ and $\mathrm{Na}-\mathrm{Mg}-\mathrm{Ca}-\mathrm{HCO}_{3}$ types and $\mathrm{Na}-\mathrm{Mg}-\mathrm{Ca}-\mathrm{Cl}-\mathrm{HCO}_{3}$ type of water is also found at some places. Based on $\mathrm{Cl}^{-}$and $\mathrm{SO}_{4}{ }^{2-}$ concentrations groundwater is normal chloride and normal sulphate water, respectively. In terms of SAR and EC values water is excellent for irrigation purpose. The isotopic composition also suggests some segregation of groundwater from the different aquifers and indicates different ages of recharge.
\end{abstract}

Key words: EC, Global meteoric water line, Hydrochemistry, Stable and radioactive isotopes

\section{INTRODUCTION}

Chapai Nawabganj town is situated in the north-western part of Bangladesh. The

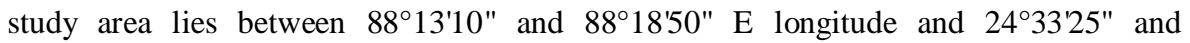
24.37'40" N latitude covering an area of about $33 \mathrm{~km}^{2}$ (Banglapedia 2003 and BBS 2010) under Chapai Nawabganj district. The study area is situated close to the present course of the river Mahananda flowing through the northern and south-eastern part of Chapai Nawabganj Town (Fig. 1).

In the study area, the recent floodplain comprises predominantly of fluvial deposits. The Barind tract is composed of well-oxidized alluvial sediment, which is reddish brown in color with the presence of ferruginous and calcareous nodules. The objectives of this study include the comparing of groundwater quality with national and international water

\footnotetext{
*Corresponding author:<mizan@juniv.edu>.
} 
quality standard for justifying its use for domestic, industrial and irrigation purposes. The study also involed use of an isotope approach with naturally occurring isotope tracers ${ }^{2} \mathrm{H}$, ${ }^{18} \mathrm{O}$ and ${ }^{3} \mathrm{H}$ to characterize the aquifers for identifying origins of groundwater and possible, recharge sources.

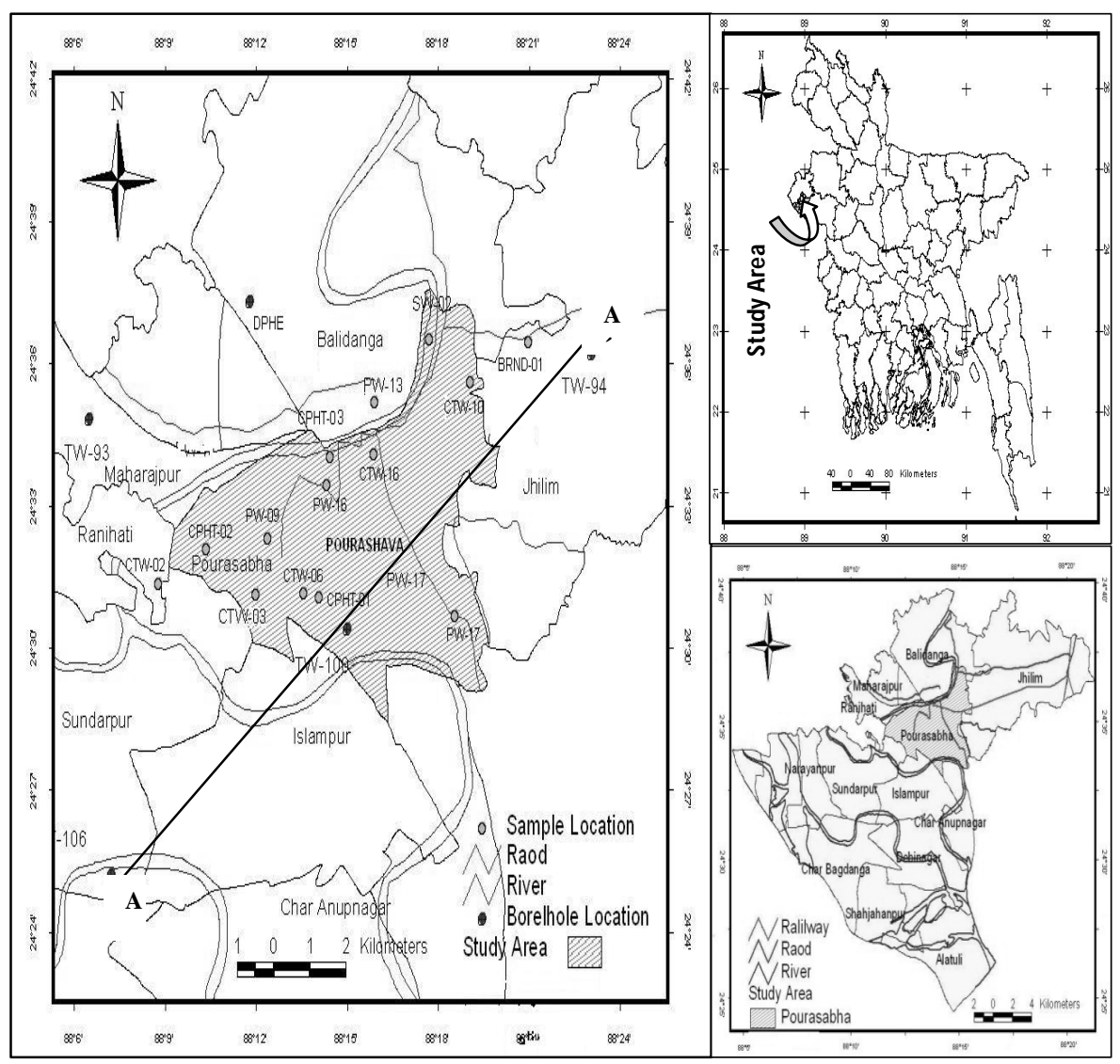

Fig. 1. Location, water samples and bore log position map of the study area.

Hydrostratigraphy of the study area up to $100 \mathrm{~m}$ depth was established from the analysis of the bore logs. A generalized subsurface lithogical cross section AA' (Fig. 2) was drawn based on available borelog data. From this cross-section, the aquifer system of the study area can be divided into upper aquitard, middle aquifer and lower aquitard. The single aquifer in this zone is different in both geometry and permeability; which causes complex groundwater flow in the aquifer. The aquifer varies widely in depth and thickness, reflecting mainly unconfined to confined in nature. The thickness of the aquifer is much higher in the central and southern part of the study area in comparison to the eastern part. 


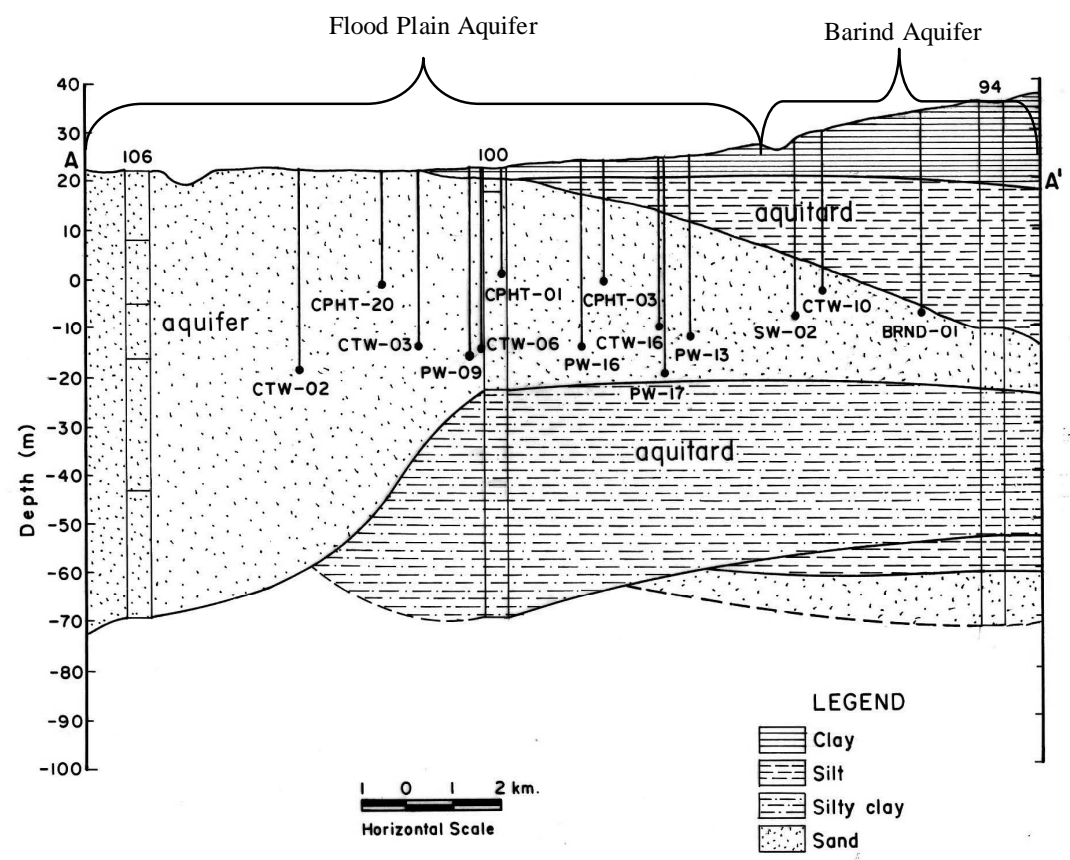

Fig. 2. Lithological cross-section along the line AA'.

Groundwater level data of 1988 - 2008 for seven observation wells were used to study the piezometry of the study area. Groundwater level rises with the initiation of monsoonal rainfall in the month of June whereas little contribution of rainfall is observed in river water level (Fig. 3a, b). In addition it has been concluded that the influence of river stage is very significant regarding the recharge and discharge of the aquifer, nearer to rivers.

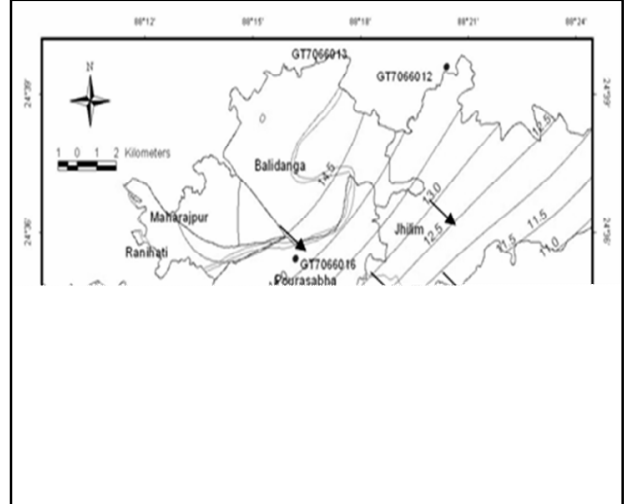

Fig. 3a. Contour map of minimum groundwater elevation (mPWD) in 2005.

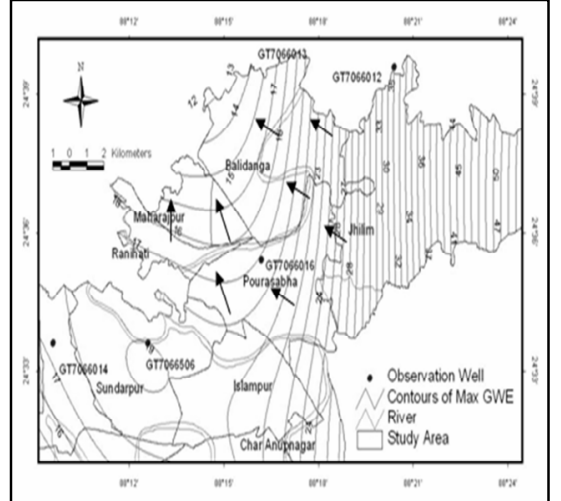

Fig. 3b. Contour map of maximum groundwater elevation (mPWD) in 2005. 


\section{MATERIALS AND METHODS}

Hydrogeological, hydrological and climatic data; previous reports, maps and images were collected from different organizations such as Bangladesh Water Development Board (BWDB), Bangladesh Meteorological Department (BMD) and Department of Public Health Engineering (DPHE).

Field work was mainly done for collection and field measurement of physicochemical parameters of water samples. Ground- and surface water samples were collected following sampling techniques standard of the USGS (1998) water chemistry sampling protocol from 1 to 3 June, 2008. Groundwater samples were collected from 14 hand tube wells and the depth varies from $21 \mathrm{~m}$ to $46 \mathrm{~m}$. The geographical locations of the tube wells were determined with a GARMIN handheld global positioning system (GPS). The approximate depth of each well was noted from the record preserved and described by the well owners. The samples were collected in $500 \mathrm{ml}$ HDPE bottles, after pumping continuously 15 - 30 minutes until the temperature, electrical conductivity (EC) and $\mathrm{pH}$ reading had stabilized. Standard procedure of filtering inorganic constituents in whole water samples through a $0.45 \mu \mathrm{m}$ pore-size disposable capsule filter has been used during sampling. All the samples are acidified in the field for the determination of cations. The environmental sensitive physical parameters like temperature, redox potential (Eh), $\mathrm{pH}$, $\mathrm{EC}$, DO were determined in the field by portable $\mathrm{pH}$ meter (Sension1, HACH Company, USA), EC meter (Sension-5, HACH Company, USA), DO meter (Sension-6 HACH Company, USA). HCO-3 was determined by digital titrator (Model 16900, HACH Company, USA).

The hydrochemical analysis has been carried out in the different laboratories of Atomic Energy Research Establishment (AERE), Ganakbari, Savar, Dhaka following the standard procedures recommended by APHA (1995). $\mathrm{Cl}, \mathrm{SO}_{4}{ }^{2-}, \mathrm{NO}_{3}{ }^{-}, \mathrm{SiO}_{2}$ were determined by UV-VIS Spectrophotometer (Model-DR/4000U, Version-2.42, HACH, U.S.A), $\mathrm{Na}^{+}$and $\mathrm{K}^{+}$were determined by Digital Flame Photometer (Model 381), $\mathrm{Ca}^{2+}$, $\mathrm{Mg}^{2+}$, and $\mathrm{Fe}_{\mathrm{Total}}, \mathrm{Mn}^{2+}$ were determined by Atomic Absorption Spectrophotometer (Shimadzu Company, Model AA 6800, Japan) and the arsenic was determined by Atomic Absorption Spectrophotometer using hydride generator (Shimadzu Company, ModelHVG-1). The accuracy and precision of the above mentioned analyses were tested through running duplicate analyses on selected samples. Standard reference materials (SRM-1640 and SRM-1643e of National Institute of Scientific and Technology, USA) were used to check accuracy of the methods. The relative standard deviation for all the samples was within $\pm 5 \%$. All samples were diluted several times to adjust for the operating range and were analyzed. 
The stable isotopes $\left(\delta^{2} \mathrm{H}\right.$ and $\left.\delta^{18} \mathrm{O}\right)$ and tritium analyses were performed using the $\mathrm{CO}_{2}$ equilibrium method and the chromium reduction method for $2 \mathrm{H} / 1 \mathrm{H}$ ratios, followed by analysis with an Isotope Ratio Mass Spectrometer (IRMS) using the conventional method (Coplen 1996) at the Isotope Hydrology Laboratory of International Atomic Energy Agency (IAEA) in Vienna, Austria.

The sodium adsorption ratio (SAR) values for each water sample were calculated by using following equation (Richard 1954), where the concentrations are reported in meq/l.

$$
\mathrm{SAR}=\frac{N a}{\sqrt{\frac{C a+M g}{2}}}
$$

Arc GIS 9.2 was used for the preparation of different maps and graphical interpretation of water level data and AquaChem4.0 software was used for graphical analysis of water chemistry data.

\section{RESULTS AND DISCUSSIONS}

Concentrations of different physico-chemical parameters, major and minor constituents of groundwater are given in Tables 1 and 2 , respectively. On site measurement of EC of groundwater ranges from 450 to $1706 \mu \mathrm{S} / \mathrm{cm}$ and most of the floodplain aquifer water samples show negative Eh value which indicates relatively reducing condition whereas the Barind aquifer water samples show positive Eh value indicating oxidizing condition. The Barind aquifer water samples are characterized by slightly acidic $\mathrm{pH}$ (average 6.96), DO (average $0.20 \mathrm{mg} / \mathrm{l}$ ) and temperature (average $25.98^{\circ} \mathrm{C}$ ). Floodplain aquifer samples show higher values of $\mathrm{pH}$ (average 7.18), DO (average $0.28 \mathrm{mg} / \mathrm{l}$ ) and temperature (average $26.57^{\circ} \mathrm{C}$ ), than the Barind aquifer water samples.

Chemical composition of the Barind aquifer water is characterized by high concentrations of $\mathrm{Mg}^{2+}$ (average $48.65 \mathrm{mg} / \mathrm{l}$ ), $\mathrm{SiO}_{2}$ (average $50.02 \mathrm{mg} / \mathrm{l}$ ) and low concentrations of $\mathrm{Fe}$ (average $0.90 \mathrm{mg} / \mathrm{l}$ ), $\mathrm{Mn}^{2+}$ (average $0.12 \mathrm{mg} / \mathrm{l}$ ), $\mathrm{SO}_{4}{ }^{2-}$ (average 17.53 $\mathrm{mg} / \mathrm{l})$ and $\mathrm{NO}^{3-}$ (average $\left.1.31 \mathrm{mg} / \mathrm{l}\right)$.

Floodplain aquifer water are also characterized by high concentrations of $\mathrm{HCO}_{3}$ (average $412 \mathrm{mg} / \mathrm{l}$ ) and $\mathrm{Ca}_{2+}$ (average $42.71 \mathrm{mg} / \mathrm{l}$ ), $\mathrm{Fe}$ (average $3.63 \mathrm{mg} / \mathrm{l}$ ), $\mathrm{Mn}_{2+}$ (average $0.33 \mathrm{mg} / \mathrm{l}$ ), $\mathrm{NO}^{3-}$ (average $8.15 \mathrm{mg} / \mathrm{l}$ ), SO4${ }^{2-}$ (average $39.40 \mathrm{mg} / \mathrm{l}$ ) and As (average 67.05 $\mu \mathrm{g} / \mathrm{l}$ ) and low concentrations of $\mathrm{Mg}^{2+}$ (average $33.92 \mathrm{mg} / \mathrm{l}$ ). High concentrations of $\mathrm{Ca}^{2+}$ and $\mathrm{HCO}^{3-}$ occur in the central part of pourashava, which indicate current recharge of groundwater (Azad et al. 2000). 
Table 1. Concentrations of physico-chemical properties of groundwater samples.

\begin{tabular}{|c|c|c|c|c|c|c|c|c|c|}
\hline Sample ID & & $\begin{array}{l}\text { Longitude } \\
\text { (E) }\end{array}$ & $\begin{array}{l}\text { Latitude } \\
(\mathrm{N})\end{array}$ & $\begin{array}{c}\text { Well depth } \\
\text { (m) }\end{array}$ & $\mathrm{pH}$ & $\begin{array}{c}\mathrm{Eh} \\
(\mathrm{mV})\end{array}$ & $\begin{array}{l}\text { Temp } \\
\left({ }^{\circ} \mathrm{C}\right)\end{array}$ & $\begin{array}{c}\mathrm{EC} \\
(\mu \mathrm{S} / \mathrm{cm})\end{array}$ & $\begin{array}{c}\mathrm{DO} \\
(\mathrm{mg} / \mathrm{l})\end{array}$ \\
\hline BRND-01 & \multirow{7}{*}{ 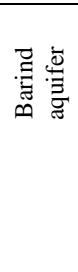 } & 88.31998 & 24.61219 & 35 & 6.78 & 14.6 & 25.7 & 811 & 0.13 \\
\hline CTW-10 & & 88.30545 & 24.60600 & 34 & 7.02 & 0.6 & 25.8 & 578 & 0.04 \\
\hline PW-17 & & 88.30177 & 24.56891 & 46 & 7.01 & 1.3 & 26 & 496 & 0.06 \\
\hline SW-02 & & 88.29540 & 24.61266 & 37 & 7.03 & 0.2 & 26.4 & 789 & 0.58 \\
\hline PW-13 & & 88.28175 & 24.60269 & 38 & 7.09 & -3 & 26.6 & 510 & 0.51 \\
\hline PW-16 & & 88.26998 & 24.58963 & 38 & 6.93 & 6.2 & 26.8 & 579 & 0.05 \\
\hline CTW-02 & & 88.22831 & 24.57394 & 40 & 7 & 1.9 & 26.2 & 513 & 0.18 \\
\hline PW-09 & \multirow{7}{*}{ 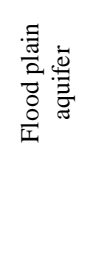 } & 88.25536 & 24.5812 & 39 & 7.12 & -4.8 & 26.6 & 1209 & 1.41 \\
\hline CTW-16 & & 88.28152 & 24.59452 & 35 & 7.36 & -18.9 & 26.4 & 450 & 0.09 \\
\hline CTW-06 & & 88.26422 & 24.57248 & 38 & 7.23 & -11.3 & 27.4 & 1706 & 0.11 \\
\hline СРНТ-01 & & 88.26806 & 24.57183 & 21 & 7.15 & -6.8 & 26.8 & 959 & 0.04 \\
\hline CTW-03 & & 88.25233 & 24.5723 & 37 & 7.23 & -11.2 & 26.7 & 554 & 0.12 \\
\hline СРНТ-02 & & 88.24010 & 24.57948 & 23 & 7.25 & -12 & 25.7 & 513 & 0.14 \\
\hline СРНТ-03 & & 88.27071 & 24.59397 & 24 & 7.45 & -23.7 & 26.5 & 1167 & 0.15 \\
\hline
\end{tabular}

Table 2. Concentrations of major cations and anions in groundwater samples.

\begin{tabular}{|c|c|c|c|c|c|c|c|c|c|c|c|c|c|}
\hline \multicolumn{2}{|c|}{ Sample ID } & $\begin{array}{c}\mathrm{Na}^{+} \\
(\mathrm{mg} / \mathrm{l})\end{array}$ & $\begin{array}{c}\mathrm{K}^{+} \\
(\mathrm{mg} / \mathrm{l})\end{array}$ & $\begin{array}{c}\mathrm{Ca}^{2+} \\
(\mathrm{mg} / \mathrm{l})\end{array}$ & $\begin{array}{l}\mathrm{Mg}^{2+} \\
(\mathrm{mg} / \mathrm{l})\end{array}$ & $\begin{array}{c}\mathrm{Fe}^{+} \\
(\mathrm{mg} / \mathrm{l})\end{array}$ & $\begin{array}{l}\mathrm{Mn}^{2+} \\
(\mathrm{mg} /)\end{array}$ & $\begin{array}{c}\text { As } \\
(\mu \mathrm{g} / 1)\end{array}$ & $\begin{array}{c}\mathrm{SiO}_{2} \\
(\mathrm{mg} / \mathrm{l})\end{array}$ & $\begin{array}{c}\mathrm{HCO}_{3} \\
(\mathrm{mg} / \mathrm{l})\end{array}$ & $\begin{array}{c}\mathrm{Cl}^{-} \\
(\mathrm{mg} / \mathrm{l})\end{array}$ & $\begin{array}{c}\mathrm{NO}_{3}^{-} \\
(\mathrm{mg} / \mathrm{l})\end{array}$ & $\begin{array}{l}\mathrm{SO}_{4}{ }^{2-} \\
(\mathrm{mg} / \mathrm{l})\end{array}$ \\
\hline BRND-01 & \multirow{7}{*}{ 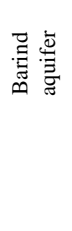 } & 68.63 & 12.34 & 53.34 & 35.22 & 0.7 & 0.05 & 0.08 & 55.56 & 355 & 188.24 & 3.646 & 26.8 \\
\hline CTW-10 & & 48.02 & 8.75 & 38.62 & 25.61 & 0.01 & 0.05 & 0.08 & 49.59 & 378 & 17.39 & 0.726 & 8.132 \\
\hline PW-17 & & 70.57 & 4.21 & 29.77 & 26.38 & 0.01 & 0.325 & 0.08 & 49.14 & 439 & 47.62 & 0.115 & 13.569 \\
\hline SW-02 & & 40.38 & 12 & 26.9 & 107.37 & 2.88 & 0.05 & 10.99 & 45.77 & 440 & 19.66 & 0.753 & 21.609 \\
\hline PW-13 & & 23.12 & 6.77 & 29.69 & 28.83 & 0.56 & 0.373 & 17.94 & 45.0 & 420 & 38.93 & 1.779 & 18.871 \\
\hline PW-16 & & 54.32 & 13.84 & 43.9 & 35.05 & 6.87 & 0.133 & 112.88 & 34.44 & 486 & 142.3 & 8.056 & 51.158 \\
\hline CTW-02 & & 7.83 & 7.6 & 32.22 & 26.77 & 14.77 & 0.518 & 167.73 & 41.48 & 447 & 3.14 & 9.65 & 0.166 \\
\hline PW-09 & \multirow{7}{*}{ 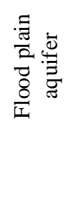 } & 40.33 & 21 & 60.95 & 42.37 & 9.26 & 0.361 & 180.34 & 30.31 & 494 & 175.81 & 5.099 & 51.267 \\
\hline CTW-16 & & 9.53 & 5.89 & 21.96 & 18.83 & 1.58 & 0.181 & 62.73 & 35.51 & 268 & 14.38 & 2.754 & 1.209 \\
\hline CTW-06 & & 146.75 & 25.88 & 82.45 & 52.84 & 0.21 & 0.602 & 17.68 & 40.41 & 490 & 392.37 & 4.253 & 227.31 \\
\hline CPHT-01 & & 44.58 & 18.27 & 63.23 & 35.49 & 0.01 & 0.698 & 44.45 & 46.23 & 466 & 88.81 & 6.646 & 17.703 \\
\hline CTW-03 & & 20.28 & 11.16 & 26.62 & 20.68 & 1.02 & 0.289 & 22.11 & 42.25 & 255 & 28.69 & 5.031 & 10.124 \\
\hline СРHТ-02 & & 10.51 & 7.56 & 23.5 & 43.61 & 0.01 & 0.05 & 24.51 & 42.09 & 305 & 9.84 & 5.211 & 2.442 \\
\hline CPHT-03 & & 175.88 & 24.82 & 42.55 & 34.69 & 0.01 & 0.133 & 20.12 & 27.09 & 489 & 157.18 & 33.039 & 13.722 \\
\hline
\end{tabular}

The chemical characteristics of water quality data have been illustrated in the Piper (Piper 1944) Trilinear diagram (Fig. 4). Interpretation of the hydrochemical data implies that the groundwater samples PW-13, SW-02, PW-16, CTW-02, PW-09, BRND-01, CTW-16, CPHT-01, CTW-03, CPHT-02, and CTW-10 belong to Ca-Mg- $\mathrm{HCO}_{3}$ type water and is the region of water of temporary hardness. Sample CTW-06 belongs to saline $\left(\mathrm{Na}^{+}+\mathrm{K}^{+}\right.$and $\left.\mathrm{Cl}^{-}+\mathrm{SO}_{4}{ }^{2-}\right)$ type water. PW-17, CPHT-03 belongs to mixing type water $\left(\mathrm{Ca}-\mathrm{Mg}-\mathrm{Na}-\mathrm{HCO}_{3}-\mathrm{Cl}\right)$. All of these samples have low to negligible chloride content and secondary alkalinity exceeds $50 \%$. These are all pure meteoric waters, which have not undergone any specific chemical changes. From the observation of Piper diagram, it is concluded that water of the study area is $\mathrm{Ca}-\mathrm{Mg}-\mathrm{HCO}_{3}$ type. 


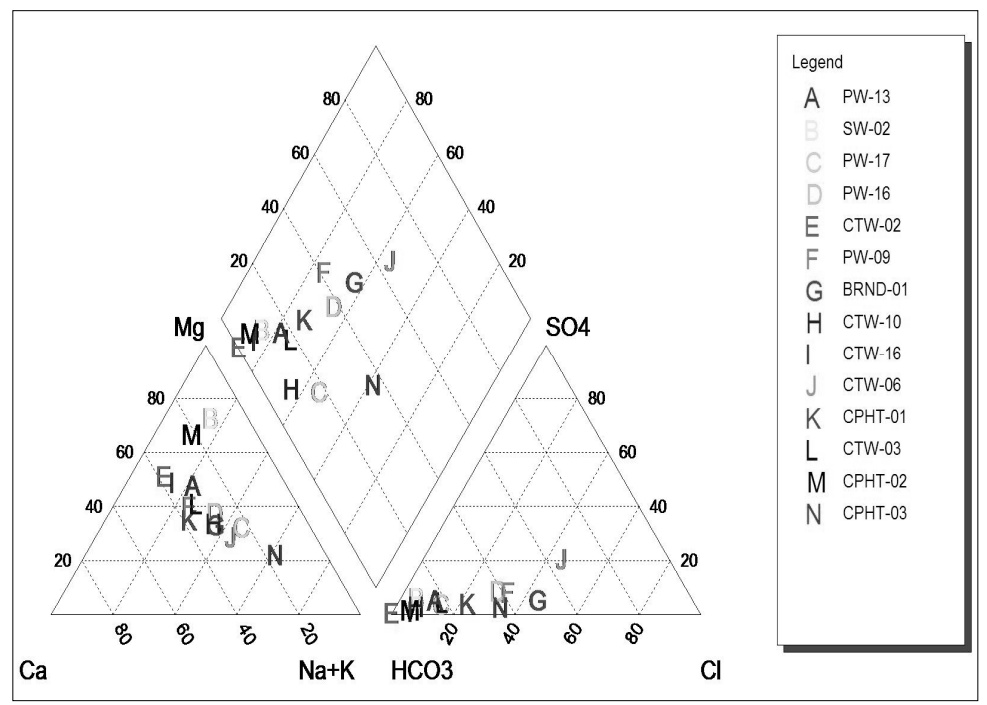

Fig. 4. Piper trilinear diagram of the groundwater samples.

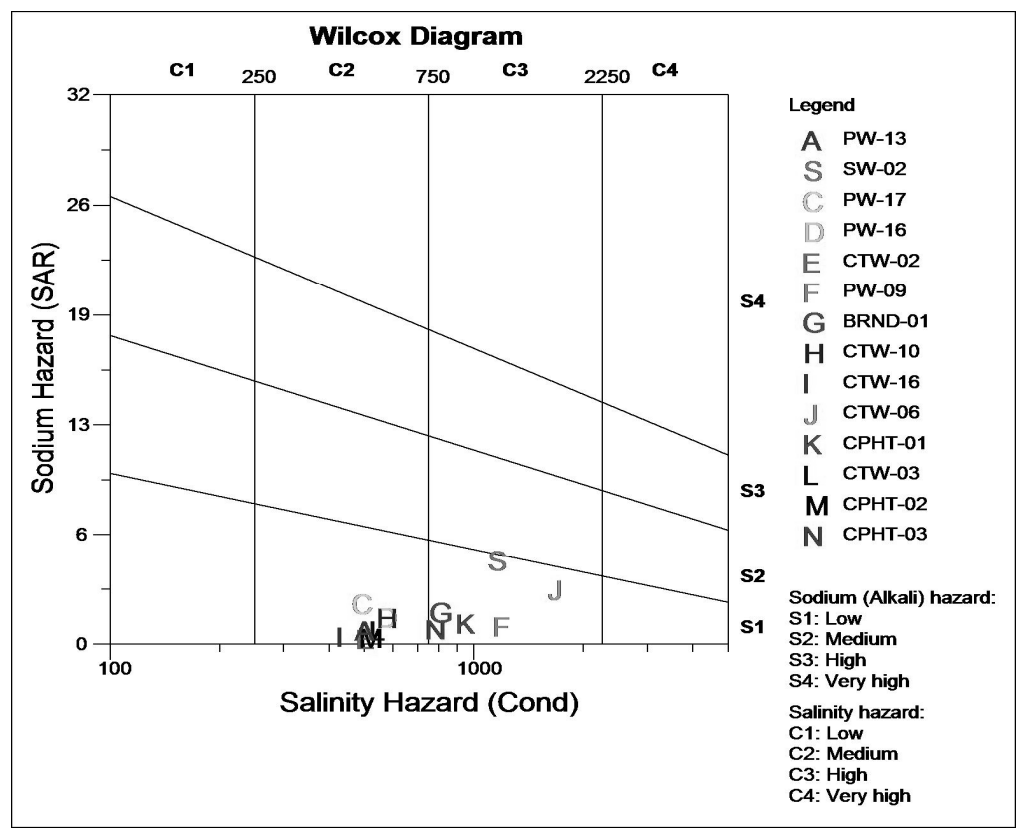

Fig. 5. Simple water classification for irrigation according to US Salinity Laboratory's diagram.

In terms of drinking water quality standard (Table 3), most of the ions of groundwater are within the limit of drinking water quality standard of both DoE (1997) and WHO (2008) but in some samples $\mathrm{K}^{+}, \mathrm{Fe}, \mathrm{Cl}^{-}$and As concentrations exceed the drinking water quality standard. Water from the floodplain aquifer exhibits higher arsenic 
concentrations. All of the floodplain aquifer samples exceed WHO (2008) standard and four samples exceed DoE (1997) standard. In the Barind aquifer, all water samples show concentrations of As below the WHO (2008) standard and only one water sample (SW02) exceeds WHO (2008) but below DoE (1997) standard. Most of the groundwater samples of Chapai Nawabganj Pourashava are arsenic contaminated. The highest concentrations (180.34 $\mu \mathrm{g} / \mathrm{l})$ present in PW-09 in floodplain aquifer at a depth of $39 \mathrm{~m}$ in production well of Pourashava, Nama Sankar Bati (Natun Hat), Ward No. 11. The severely arsenic contaminated groundwater is dominantly $\mathrm{Mg}-\mathrm{Ca}-\mathrm{HCO}_{3}$ type water with neutral to basic $\mathrm{pH}$, often moderately hard to very hard hardness with much bicarbonate concentrations. As the reducing condition is prevailing in groundwater it is likely to be the reason of arsenic mobilization. Groundwater of the study area is suitable for industrial purposes except few groundwater samples that are not maintaining conformity with the recommended concentration.

Table 3. Comparison of groundwater quality parameters with WHO (2008) guideline values for chemicals that are of health significance in drinking-water and DoE (1997) standards for drinking water.

\begin{tabular}{|c|c|c|c|c|c|c|}
\hline \multirow{2}{*}{\multicolumn{2}{|c|}{$\begin{array}{l}\text { Water quality } \\
\text { parameters }\end{array}$}} & \multicolumn{2}{|c|}{ WHO standard (2008) } & \multirow{2}{*}{$\begin{array}{l}\text { Bangladesh } \\
\text { standard } \\
\text { (DoE, 1997) }\end{array}$} & \multicolumn{2}{|c|}{ Study area } \\
\hline & & $\begin{array}{c}\text { Max. } \\
\text { acceptable }\end{array}$ & $\begin{array}{c}\text { Max } \\
\text { allowable }\end{array}$ & & Range & Average \\
\hline \multirow{4}{*}{ 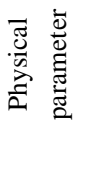 } & $\mathrm{pH}$ & 6.5 & 8.5 & $6.5-8.5$ & $6.78-7.5$ & 7.12 \\
\hline & TDS (mg/l) & 1000 & & 1000 & $307-1232$ & 575.36 \\
\hline & Hardness & 100 & 500 & $200-500$ & $132-509$ & 259.66 \\
\hline & $\mathrm{Na}(\mathrm{mg} / \mathrm{l})$ & 200 & & 200 & $7-175$ & 54.34 \\
\hline \multirow{3}{*}{ 莞 } & $\mathrm{K} »$ & - & - & 12 & $4-25.8$ & 12.87 \\
\hline & $\mathrm{Ca} "$ & - & - & 75 & $21.9-82$ & 41.12 \\
\hline & $\mathrm{Mg} ”$ & 50 & 150 & $30-35$ & $18.8-107$ & 38.12 \\
\hline \multirow{4}{*}{ 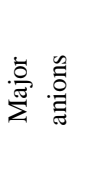 } & $\mathrm{HCO}_{3} "$ & - & - & - & $255-494$ & 409.43 \\
\hline & $\mathrm{Cl}^{-}$ & 200 & 600 & $150-600$ & $3-392$ & 94.60 \\
\hline & $\mathrm{SO}_{4}{ }^{2-,}$ & - & 250 & 400 & $0.1-227$ & 33.15 \\
\hline & $\mathrm{NO}_{3}^{2-,}$ & 50 & - & 10 & $0-33$ & 6.20 \\
\hline \multirow{3}{*}{ 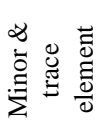 } & $\mathrm{Fe} "$ & 0.3 & 3 & $0.3-10$ & $0-14$ & 2.79 \\
\hline & $\mathrm{Mn} ”$ & 0.5 & - & 0.1 & $0-0.7$ & 0.27 \\
\hline & As $\mu \mathrm{g} / 1$ & 10 & - & 50 & $0-180$ & 67.05 \\
\hline
\end{tabular}

In terms of SAR (Raghunath 1990) and EC values (Wilcox 1967) it is observed that groundwater is satisfactory for irrigation purposes but it is doubtful for using irrigation purposes because of high arsenic concentration. From the observation of both SAR and $\mathrm{EC}$ value it is found that most of the water samples in the study area are belonging to $\mathrm{C} 2$ field and rest of the groundwater samples belong to C3 field (Fig. 5). 
The water samples for environmental isotopic analyses $\left({ }^{18} \mathrm{O},{ }^{2} \mathrm{H},{ }^{13} \mathrm{C},{ }^{3} \mathrm{H}\right.$ and $\left.{ }^{14} \mathrm{C}\right)$ were conducted and collected from the IAEA, Vienna, Austria. The result of environmental isotopic analyses is given in Table 4.

Table 4. Concentrations of environmental isotopes of groundwater samples.

\begin{tabular}{lccclcc}
\hline $\begin{array}{c}\text { Sample } \\
\text { ID }\end{array}$ & $\begin{array}{c}\text { Well depth } \\
(\mathrm{m})\end{array}$ & $\begin{array}{c}\delta^{18} \mathrm{O} \\
(\% \text { oVSMOW })\end{array}$ & $\begin{array}{c}\delta^{2} \mathrm{H} \\
(\% \text { VSMOW })\end{array}$ & $\begin{array}{l}\delta^{13} \mathrm{C} \% \text { o } \\
(14 \mathrm{C})\end{array}$ & $\begin{array}{c}3 \mathrm{H} \\
(\mathrm{TU})\end{array}$ & $\begin{array}{c}{ }^{14} \mathrm{C} \\
(\mathrm{pMC})\end{array}$ \\
\hline PW-13 & 38 & -4.72 & -32.7 & -11.91 & 3.82 & 98.15 \\
SW-02 & 37 & -4.13 & -29.1 & -8.08 & 1.05 & 81.38 \\
PW-17 & 46 & -3.62 & -28 & -10.26 & 1.15 & 78.33 \\
PW-16 & 38 & -4.3 & -31.4 & -11.91 & 3.64 & 99.62 \\
CTW-02 & 40 & -5.3 & -37.3 & - & 3.2 & - \\
PW-09 & 39 & -4.99 & -36.8 & -14.18 & 2.59 & 95.58 \\
BRND-01 & 35 & -3.44 & -25.1 & - & 0.32 & - \\
CTW-10 & 34 & -3.56 & -25.6 & -8.75 & 0.42 & 82.24 \\
CTW-16 & 35 & -3.92 & -28.4 & - & 4.26 & - \\
CTW-06 & 38 & -5.37 & -35 & - & 3.73 & - \\
CPHT-01 & 21 & -4.96 & -33.1 & - & 5 & - \\
CTW-03 & 37 & -5.04 & -32.3 & - & 3.53 & - \\
CPHT-02 & 23 & -4.02 & -26.6 & - & 4.42 & - \\
CPHT-03 & 24 & -5.68 & -37.7 & - & 1.25 & - \\
\hline
\end{tabular}

Results of stable isotope analysis for $\delta^{18} \mathrm{O}$ and $\delta^{2} \mathrm{H}$ are plotted in Fig. 6. The plot presents data in relation to the Global Meteoric Water Line (GMWL) of Craig (1961). This line represents the results of world-wide precipitation measurements of $\delta^{18} \mathrm{O}$ and $\delta^{2} \mathrm{H}$ and is defined by the following equation:

$$
\delta^{2} \mathrm{H}=8 \delta^{18} \mathrm{O}+10 .
$$

For the present study the local meteoric line (for Shillong, India) is also drawn. The local meteoric line is very similar to the WML and is defined by the equation:

$$
\delta^{2} \mathrm{H}=8 \delta^{18} \mathrm{O}+12
$$

The results of stable isotopic compositions for $\delta^{18} \mathrm{O}$ and $\delta^{2} \mathrm{H}$ are plotted in Fig. 6 and the WML is drawn on the plot. Most of the sampled water depart significantly from this line, indicating an origin from rain and local rivers; and it represents that some evaporative fractionation has occurred before infiltration.

Groundwaters in the study area show some spatial variation with the most depleted (range -5.04 to $-5.68 \%$ ) and also with a few slightly enriched (range -3.44 to $-4.99 \%$ ) compositions of $\delta^{18} \mathrm{O}$ in the Holocene aquifer that lies in the central part of Pourashava. Most likely, it relates to increased inputs of rain and river recharge locally during flood time. The isotopic distinctions in groundwater in this study area suggests some 
segregation of groundwaters from the different aquifers and may indicate different ages of recharge. Groundwater from the two aquifers are therefore likely to have been recharged at different periods. This is to some extent confirmed by radioactive isotope (tritium) data for groundwaters from this study area.

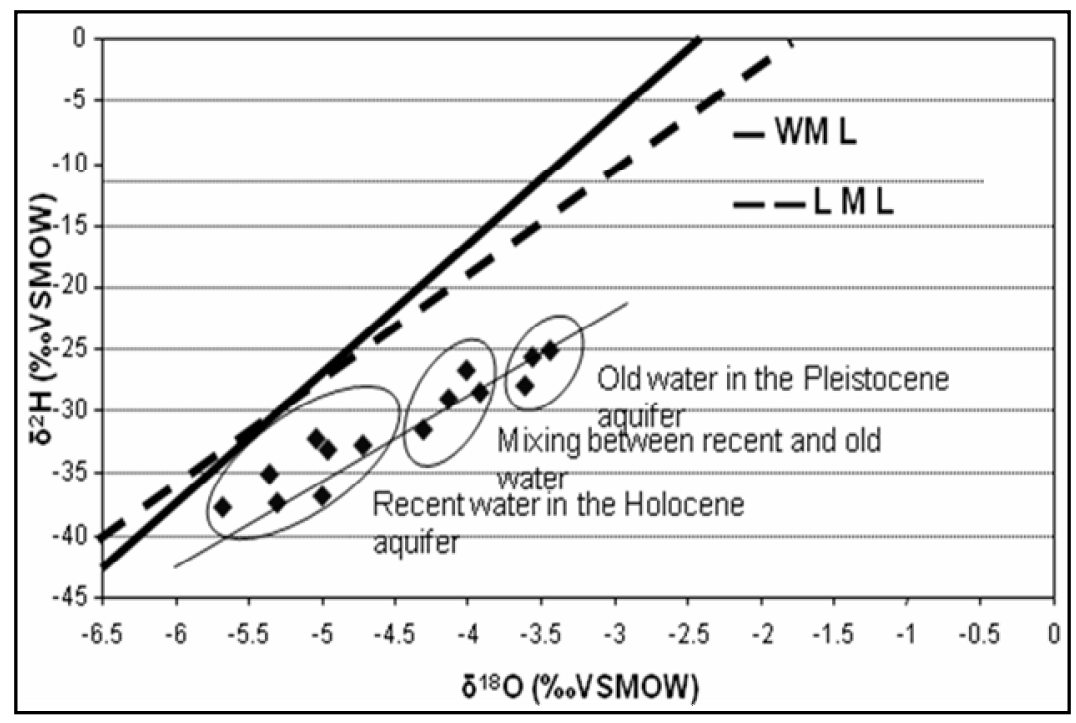

Fig. 6. Relationship between oxygen-18 and deuterium in the groundwater of the study area and Mahananda river.

It is seen from the tritium distribution plot, the samples with very low tritium $(<1$ TU) are mostly from the eastern part of town. These samples have a $\delta^{18} \mathrm{O}$ value of between about -4 and $-5 \%$. Two samples in the eastern part (SW-13 and PW-17) have slightly higher tritium values (1.05 and $1.15 \mathrm{TU})$, but these samples have very high $\delta^{18} \mathrm{O}$ values, indicating draw down of water from a nearby waterbody or pond. Based on the tritium and stable isotope values, it can be concluded that the source of water in this arsenic-free reservoir is likely from recharge much to the east and/or north (could include river recharge). Low tritium values in the eastern side samples indicate the presence of predominantly older (pre-1960s) water at depth. It is unlikely that this water is much older than 100 years, as the older waters in other regions that had previously been seen at depth of about $100 \mathrm{~m}$ had a $\delta^{18} \mathrm{O}$ value of about $-5 \%$. This aquifer may continue to provide safe water. Samples with low tritium in the western part of town have a much lower $\delta^{18} \mathrm{O}$ value of about $-5.5 \%$ or so and likely have a different source of water, but not from the Pleistocene aquifer of eastern side.

C-14 activity of the analyzed groundwater varies from 99.62 to $81.38 \mathrm{pMC}$ in the study area. The result indicates that the groundwater residence times in $\sim 30$ to 1700 years 
BP. Shallow groundwater collected from the study area show relatively high ${ }^{14} \mathrm{C}$ values which indicate modern recharge from precipitation or river waters.

\section{CONCLUSION}

The general trend of groundwater flow is towards the south-east direction in dry season and north-west direction in wet season. The fluctuation of groundwater level ranges from 7.58 to $18.12 \mathrm{mPWD}$. The average EC of the Barind aquifer and floodplain aquifer is 668.33 and $816 \mu \mathrm{S} / \mathrm{cm}$, respectively. The average $\mathrm{pH}$ of floodplain aquifer is about 7.18 which are a bit higher than the Barind aquifer. Groundwater is mainly $\mathrm{Mg}-\mathrm{Ca}-$ $\mathrm{HCO}_{3}$ and $\mathrm{Ca}-\mathrm{Mg}-\mathrm{Na}-\mathrm{HCO}_{3}$ type of water. Water samples from floodplain area contain high arsenic and exceed drinking water quality standard of Bangladesh. From the above observations, it can be concluded that most of the groundwater samples are suitable for drinking and minor treatment may be required except arsenic. In terms of SAR and EC values it is observed that the water of the study area is excellent quality water for irrigation purpose. The spatial variation of $\delta^{18} \mathrm{O}$ in groundwaters of Chapai Nawabganj town shows mostly depleted and a few slightly enriched compositions in the Holocene flood plain aquifer, indicating the inputs of rain and river recharge locally during flood time. Two subsystems could be identified in the study area based on hydrochemical, stable isotope and tritium data. Subsystem A with low arsenic content and pre-1960s water was formed in the eastern part of the study area. Sub-system B is consisted of arsenic rich and recent recharge water in the central part of the study area. Therefore water in the eastern part of the study area is safe for drinking purpose and continue to be so in near future.

\section{ACKNOWLEDGEMENTS}

The first author is indebted to the Institute of Nuclear Science \& Technology, Atomic Energy Research Establishment, Ganakbari, Savar, Dhaka for providing Laboratory facilities during the research. The support for environmental isotope analysis provided by IAEA, Vienna, Austria is gratefully acknowledged.

\section{REFERENCES}

APHA, 1995. Standard methods for the examination of water and wastewater. 19th edn. American Public Health Association, Washington, DC.

Azad, M.A. and K. Bashar. 2000. Groundwater zonation of Nawabganj Sadar Thana and its relation to groundwater chamistry. Bangladesh J. Geology 19: 57-71.

Banglapedia. 2003. National Encyclopedia of Bangladesh. Vol. 9, Asiatic Society of Bangladesh.

Bangladesh Bureau of Statistics (BBS). 2010. Dhaka, Bangladesh.

Coplen, T.B. 1996. New guidelines for reporting hydrogen, corbon, and oxygen isotope ratio data. Geochem Cosmochem Acta 60: 3359. 
Craig, H. 1961. Isotopic Variations in Meteoric Waters. Science 133:1702-1703.

Department of Environment (DoE). 1997. Environmental quality standard for Bangladesh, Dhaka.

Piper, A.M. 1944. A graphical procedure in the geochemical interpretation of water analyses. Am. Geophys. Union Trans. 25: 914-923.

Raghunath, H.M. 1990. Groundwater. Wiley Eastern Ltd., New Delhi, India. p. 563.

Richard, L. A. 1954. Diagnosis and improvement of saline and alkali soils. Agric. Handbook 60, Washington, USDA, DC. pp. 160.

USGS (United States Geological Survey). 1998. National Field Manual for the Collection of Water Quality Data, Book 9, Handbooks for Water- Resources Investigations.

Wilcox, L. V. 1955. Classification and use of irrigation waters. US Department of Agriculture, Washington DC. pp. 19.

World Health Organization (WHO). 2008. Guidelines for Drinking-Water Quality. Third Edition Incorporating the First and Second addendum, Vol. 1, Recommendations. World Health Organization, Geneva, Switzerland. pp. 668.

(Received revised manuscript on 30 August, 2014) 